\title{
ANALISIS FAKTOR FAKTOR YANG MEMPENGARUHI MINAT PEMANFAATAN DAN PENGGUNAAN TEKNOLOGI PEMBAYARAN ELEKTRONIK BERGERAK DENGAN MENGGUNAKAN MODEL UTAUT.
}

(STUDI KASUS PADA TEKNOLOGI M-DINAR PAYMENT SYSTEM)

\begin{abstract}
The purpose of this research is to analyze factors that influence behaviour intention to use technology information system and use behaviour technology information system using UTAUT (unified theory of acceptance and use of technology). That factors are performance expectancy, effort expectancy, perceived of credibility, social influence, and facilitating condition and moderated by age, gender and experience.

Sample of this research is investment using services community (M-Dinar) through internet. One hundred and twenty four respondents using M-Dinar had participated in this research. The collecting data used a questionnaire survey that posted at facebook and sent it via electronic-mail. Data were analyzed using a Moderated Regression Analysis (MRA).

The result showed only social influence that effecting behaviour intention to use M-Dinar technology significant. The other factors aren't have significant influence to behavoiur intention to use M-Dinar technology.
\end{abstract}

Keywords: performance expectancy, effort expectancy, perceived of credibility, social influence, facilitating condition, behaviour intention using technology information system and use behaviour.

\section{PENDAHULUAN}

Seiring dengan pesatnya perkembangan jaman, kebutuhan manusia akan informasi terus meningkat, informasi dapat berubah dalam waktu yang relatif singkat. Pengertian informasi adalah data yang berguna yang dapat diolah sehingga dapat dijadikan sebagai dasar dalam suatu pengambilan keputusan yang tepat (Bodnar dan Hopwood, 2005). Suatu informasi dapat dikatakan memiliki manfaat dalam proses pengambilan keputusan apabila informasi tersebut disajikan secara akurat, tepat waktu dan relevan. Informasi saat ini telah diakui sebagai salah satu sumber daya atau investasi yang patut dikembangkan oleh suatu perusahaan yang diharapkan dapat memiliki kinerja yang baik sehingga dapat menjadi suatu sumber daya penyedia informasi yang cepat dan akurat serta dapat memberikan manfaat yang besar dalam pencapaian tujuan organisasi (Komara, 2006) dalam Handayani (2007).

Sistem informasi yang berbasis komputer dapat melakukan fungsinya secara lebih tepat dan cepat serta pemprosesan datanya akan lebih murah bila dibandingkan dengan sistem manual (Wilkinson \& Cerullo, 1997) dalam Handayani (2007). Minat untuk menggunakan dan mengembangkan sistem informasi berbasis 
komputer dan aplikasinya, atau disebut end-user computing didorong oleh faktor-faktor seperti: meningkatnya pengetahuan tentang komputer, harga perangkat yang semakin murah, dan tersedianya kebutuhan jasa organisasi.

Untuk menggambarkan tingkat penerimaan akan suatu perkembangan teknologi dikembangkan suatu model yaitu Technology Acceptance Models (TAM), yang mana tujuan TAM adalah memberikan penjelasan tentang penentuan penerimaan komputer secara umum, dan memberikan penjelasan tentang perilaku atau sikap pengguna dalam suatu populasi (Davis, 1989). Setelah model TAM ini dikembangkan lagi model tentang penerimaan teknologi yaitu UTAUT, Unified Theory of Acceptance Use of Technology (Venkantesh, 2003). UTAUT bertujuan untuk menjelaskan minat pengguna dalam menggunakan teknologi atau sistem informasi dan perilaku pengguna berikutnya. Bahwa dalam UTAUT terdapat empat faktor (ekspektasi kinerja, ekspektasi usaha, pengaruh sosial dan kondisi yang memfasilitasi) penentu langsung minat menggunakan dan perilaku untuk menggunakan sistem informasi atau teknologi (Venkantesh et. Al, 2003).

Venkantesh et. al (2003) menjelaskan bahwa ekspektasi kinerja merupakan tingkat dimana seorang individu meyakini bahwa dengan menggunakan sistem informasi akan membantu dalam meningkatkan kinerjanya. Ekspektasi usaha didefinisikan sebagai tingkat kemudahan dalam menggunakan suatu sistem informasi yang akan mengurangi tenaga dan waktu seseorang dalam melaksanakan pekerjaannya. Pengaruh sosial merupakan tingkat dimana seseorang menganggap orang lain meyakinkan dirinya bahwa dia harus menggunakan sistem yang baru. Dan kondisi yang memfasilitasi merupakan sejauh mana seseorang percaya bahwa infrastruktur organisasi dan teknikal tersedia untuk mendukung sistem (Venkantesh et. al, 2003).

Penelitian mengenai pemanfaatan sistem informasi atau teknologi informasi adalah penelitian Adrianto Sugiarto Wiyono (2005) dalam Handayani (2007) mengenai Evaluasi Perilaku Penerimaan Wajib Pajak terhadap Penggunaan e-filling sebagai Sarana Pelaporan Pajak secara Online dan Realtime. Hasil penelitian ini menunjukkan bahwa kewajiban menggunakan e-filling akan menyebabkan tidak signifikannya pengaruh minat perilaku terhadap penggunaan senyatanya. Selain itu kerumitan mempunyai pengaruh yang signifikan terhadap penggunaan senyatanya, demikian pula jenis kelamin juga mempunyai pengaruh signifikan terhadap persepsi kemudahan penggunaan.

Penelitian Venkantesh et. al (2003) dan Handayani (2007) menguji faktor-faktor yang mempengaruhi minat pemanfaatan sistem informasi dan pengaruhnya terhadap penggunaan sistem informasi. Berdasarkan hasil empiris yang diperoleh disimpulkan bahwa ekspektasi kinerja mempunyai pengaruh positif signifikan terhadap minat pemanfaatan sistem informasi, variabel ekspektasi usaha berpengaruh positif signifikan terhadap minat pemanfaatan sistem informasi, faktor sosial berpengaruh positif tidak signifikan terhadap minat pemanfaatan sistem informasi, kondisi-kondisi yang memfasilitasi pemakai terbukti mempunyai pengaruh positif dan signifikan terhadap penggunaan sistem informasi, dan minat pemanfaatan sistem informasi berpengaruh positif tetapi tidak signifikan terhadap penggunaan sistem informasi.

Penelitian ini merupakan replikasi dari penelitian Venkantesh et. al (2003) dengan menambah satu variabel bebas yang mempengaruhi minat menggunakan teknologi, yaitu variabel persepsi kredibilitas. Karena selain 
empat faktor yang telah disebutkan di atas, minat seseorang dalam menggunakan teknologi tidak akan lepas dari keamanan akan sistem informasi dan tingkat kepercayaan seseorang bahwa dalam menggunakan suatu sistem informasi, keamanaan sistem tersebut yang diutamakan.

Penelitian ini akan meneliti penggunaan sistem informasi investasi M-Dinar oleh masyarakat di Indonesia. Kenapa M-Dinar, karena M-Dinar merupakan investasi emas yang menggunakan suatu sistem informasi teknologi yang dapat diakses melalui jaringan internet berupa akun elektronik yang dikenal dengan nama M-Dinar. M-Dinar.com dapat diakses dari berbagai perangkat elektronik seperti komputer, telepon genggam dan perangkat lainnya selama terhubung dengan jaringan internet.

\section{TELAAH LITERATUR DAN PENGEMBANGAN HIPOTESIS}

\section{Theory Of Reasoned Action (TRA)}

Theory of Reasoned Action (TRA) dikembangkan oleh Ajzen and Fishbein pada tahun 1975 dan 1980. TRA adalah perluasan model yang berfokus pada penentukan perilaku yang diharapkan. Berdasarkan TRA, perilaku seseorang ditentukan oleh behavioral intention (BI) untuk melakukan suatu perilaku, dan behavior intention secara bersama-sama ditentukan oleh attitude (A) dan subjective norm (SN). Behavioral intention adalah tingkat minat seseorang untuk melakukan perilaku tertentu. Attitude diartikan sebagai perasaan positif atau negatif seseorang ketika melakukan perilaku tertentu. Subjective norm mengarah pada persepsi seseorang bahwa kebanyakan orang yang penting baginya berpikir bahwa ia harus atau tidak harus melakukan perilaku tertentu. Berdasarkan TRA, attitude toward behavior ditentukan oleh kepercayaan (beliefs) yang paling menonjol tentang konsekuensi dari melakukan perilaku yang dihasilkan dari evaluasi (evaluation). Subjective norm (SN) diartikan sebagai hasil dari normative beliefs dan motivasinya untuk mengikuti harapan (motivation to comply). Kerangka TRA dapat dilihat pada gambar 1.

Theory of Reasoned Action (TRA) yang menyatakan bahwa individu akan menggunakan komputer jika mereka mengetahui adanya keuntungan atau hasil positif dalam penggunaan komputer tersebut, contohnya pekerjaan yang dapat diselesaikan lebih cepat dengan hasil yang lebih baik sehingga kinerja individu tersebut dapat dikatakan meningkat. Teori tersebut masih digunakan dalam literatur teknologi informasi sampai sekarang.

\section{Theory Planned Behaviour (TPB)}

Theory of Planned Behavior (TPB) dikembangkan oleh Ajzen dan Fishbein pada tahun 1988 dan 1991 di mana minat seseorang (behavioral intention) dipengaruhi oleh attitude toward the behavior, subjective norm, dan perceived behavioral control. Attitude toward the behavior adalah tingkat di mana kinerja dari perilaku secara positif atau negatif dinilai, subjective norm adalah persepsi tekanan sosial untuk menggunakan atau tidak menggunakan perilaku, dan perceived behavioral control adalah persepsi seseorang tentang kemampuan orang tersebut untuk melaksanakan perilaku yang diberikan. Attitude toward the behavior didapatkan dari behavioral beliefs. Behavioral beliefs adalah perilaku ketertarikan pada hasil yang diharapkan. Subjective norm 
didapatkan dari normative beliefs. Normative beliefs adalah persepsi perilaku yang diharapkan dari referensi seseorang atau kelompok yang penting seperti keluarga dan teman. Perceived behavioral control didapatkan dari control beliefs. Control beliefs adalah persepsi keberadaan faktor yang dapat memfasilitasi atau menghalangi kinerja sebuah perilaku. Kerangka TPB dapat dilihat pada gambar 2.

Asumsi dasar dari TPB adalah banyak perilaku tidak semuanya di bawah kontrol penuh individual sehingga perlu ditambakan konsep kontrol perilaku persepsian. Teori ini mengasumsikan bahwa kontrol perilaku persepsian mempunyai implikasi motivasional terhadap minat-minat, selain itu adanya kemungkinan hubungan langsung antara kontrol perilaku persepsian dengan perilaku. Jika semua perilaku dapat dikontrol sepenuhnya oleh individu-individu mendekati maksimum maka TPB akan kembali menjadi TRA.

Kontrol perilaku persepsian dalam konteks sistem teknologi informasi didefinisikan oleh Taylor dan Todd (1995) sebagai persepsi dan konstruk-konstruk internal dan eksternal dari perilaku. Kontrol ini merefleksikan pengalaman masa lalu dan juga mengantisipasi halangan-halangan yang ada. Semakin menarik sikap dan norma subyektif terhadap perilaku dan semakin besar kontrol perilaku persepsian maka semakin kuat minat seseorang untuk melakukan perilaku yang sedang dipertimbangkan.

\section{Unified Theory of Acceptance and Use of Technology (UTAUT)}

Model UTAUT disusun berdasarkan model-model penerimaan teknologi sebelumnya seperti Theory of Reason Action (TRA), Theory of Planned Behaviour (TPB), Task-Fit Technology, dan terutama adalah model Technology of Acceptance Model (TAM). UTAUT bertujuan menjelaskan minat seseorang untuk menggunakan atau menggunakan suatu sistem informasi teknologi dan perilaku pengguna berikutnya (Venkantesh et. al, 2003).

Dalam teori UTAUT ada empat faktor utama penentu langsung dari minat menggunakan atau menggunakan dan perilaku menggunakan sistem informasi teknologi, yaitu ekspektasi kinerja, ekspektasi usaha, pengaruh sosial dan kondisi yang memfasilitasi. Gender, umur, pengalaman dan sukarela penggunaan digunakan untuk memoderasi pengaruh empat faktor utama tersebut terhadap minat menggunakan dan menggunakan serta perilaku menggunakan sistem informasi teknologi.

\section{HIPOTESIS}

\section{Ekspektasi Kinerja dengan Minat Menggunakan Teknologi M-Dinar}

Penelitian berkaitan dengan perbedaan gender, menunjukkan bahwa pria memiliki kecenderungan lebih tinggi kepada tugas (Minton and Schneider (1980) dalam Venkatesh (2003)), sehingga ekspektansi kinerja yang yang memiliki fokus pada penyelesaian tugas, akan cenderung kuat pada pria. Serupa dengan gender, umur dikategorikan mempunya peran moderasi. Penelitian dalam sikap yang berhubungan dengan pekerjaan (Porter (1983) dalam Venkatesh (2003)) mengusulkan bahwa pekerja-pekerja lebih muda dan mempunyai pengalaman yang memadai akan lebih penting untuk kompensasi kompensasi ekstrinsik.

H1: Ekspektasi kinerja mempunyai pengaruh positif terhadap minat menggunakan teknologi M-Dinar dan hubungan tersebut akan dimoderasi oleh umur, gender dan pengalaman. 


\section{Ekspektasi Usaha dan Minat Menggunakan Teknologi M-Dinar}

Ekspektasi usaha (effort expectancy) didefinisikan sebagai tingkat kemudahan yang dihubungkan dengan penggunaan suatu sistem. Apabila suatu sistem mudah digunakan, maka usaha yang dilakukan tidaklah terlalu tinggi dan sebaliknya jika suatu sistem sulit digunakan, maka diperlukan usaha yang tinggi untuk menggunakannya (Venkantesh et al, 2003).

Venkatesh et al (2003) mengusulkan bahwa ekspektansi usaha (effort expectancy) lebih menonjol untuk wanita muda dan mempunyai pengalaman dibandingkan untuk pria. Penelitian sebelumnya juga mendukung pendapat bahwa eksektansi usaha akan lebih kuat sebagai penentu minat individual untuk wanita. (Venkatesh dan Morris 2000; Venkatesh et all 2000).

H2: Ekspektansi usaha mempunyai pengaruh positif terhadap minat menggunakan teknologi M-Dinar dan hubungan tersebut akan dimoderasi oleh umur, gender dan pengalaman.

\section{Persepsi Kredibilitas dan Minat Menggunakan Teknologi M-Dinar}

Persepsi kredibilitas diartikan dengan keamanan dan kepercayaan akan suatu sistem teknologi. Suatu sistem teknologi mempunyai keamanan yang dapat diandalkan maka minat seseorang akan menggunakan suatu sistem tersebut akan tinggi. Sebaliknya apabila keamanan suatu sistem tersebut tidak dapat diandalkan, maka minat seseorang untuk menggunakan suatu sistem teknologi akan rendah (Shin, 2008).

Bahwa wanita muda yang mempunyai pengalaman lebih berhati-hati dalam menggunakan sistem teknologi, karena wanita lebih mengandalkan sistem keamanan dalam menggunakan suatu sistem yang harus digunakan dalam pekerjaan sehari-hari (Shin, 2009).

H3: Persepsi Kredibilitas mempunyai pengaruh positif terhadap minat menggunakan teknologi M-Dinar dan hubungan tersebut akan dimoderasi oleh umur, gender dan pengalaman.

\section{Pengaruh Sosial dan Minat Menggunakan Teknologi M-Dinar}

Venkatesh et al (2003) mengusulkan bahwa wanita cenderung lebih sensitif kepada opini orang lain dan dengan demikian akan ditemukan bahwa pengaruh sosial akan lebih kuat ketika membentuk suatu minat menggunakan suatu teknologi baru. Kebutuhan berkumpul meningkat dengan meningkatnya umur sehingga pekerja lebih tua akan lebih terpengaruh oleh pengaruh pengaruh social dengan pengaruhnya menurun sejalan dengan meningkatnya pengalaman.

H4 : Pengaruh sosial mempunyai pengaruh positif terhadap minat menggunakan teknologi M-Dinar dan hubungan tersebut akan dimoderasi oleh gender, umur dan pengalaman

\section{Kondisi Yang Memfasilitasi dan Penggunaan Teknologi M-Dinar}

Psikologis organisasional menunjukkan bahwa pekerja-pekerja lebih tua akan merasa penting untuk menerima bantuan dan dukungan di pekerjaan mereka. Dengan demikian, jika dimoderasi oleh umur, kondisi kondisi pemfasilitasi akan mempunyai pengaruh yang signifikan ke perilaku pemanfaatan teknologi. 
H5: Kondisi kondisi pemfasilitasi mempunyai pengaruh positif terhadap perilaku penggunaan teknologi M-Dinar dan hubungan tersebut akan dimoderasi oleh umur dan pengalaman.

\section{Minat Menggunakan Teknologi M-Dinar dan Penggunaan Teknologi M-Dinar}

Sedangkan Thompson et al.(1991) menyatakan bahwa keyakinan seseorang akan kegunaan teknologi akan meningkatkan minat mereka dan pada akhirnya individu tersebut akan menggunakan teknologi dalam pekerjaannya. Venkatesh et al, (2003) menyatakan bahwa terdapat adanya hubungan langsung dan signifikan antara minat pemanfaatan teknologi terhadap penggunaan teknologi.

H6: Minat pemanfaatan teknologi layanan M-Dinar mempunyai pengaruh positif terhadap penggunaan teknologi M-Dinar.

\section{METODE PENELITIAN}

\section{Populasi dan Sampel}

Populasi dalam penelitian ini adalah komunitas pengguna layanan investasi melalui internet dalam jejaring sosial facebook. Sedangkan sampel penelitian ini adalah komunitas pengguna Dinar Emas dan Dirham Perak, salah satu komunitas pengguna layanan investasi melalui internet dalam jejaring facebook.

\section{Metode Analisis Data}

Dalam penelitian ini analisis data menggunakan pendekatan Partial Least Square (PLS). PLS adalah model persamaan Structural Equation Modeling (SEM) yang berbasis komponen atau varian. Menurut Ghozali (2006), PLS merupakan pendekatan alternatif yang bergeser dari pendekatan SEM berbasis kovarian menjadi berbasis varian.

\section{HASIL DAN PEMBAHASAN}

\section{Data Penelitian}

Data penelitian dikumpulkan dengan mengirimkan 150 kuesioner yang dilakukan secara langsung oleh peneliti kepada responden penelitian melalui email pengguna fasilitas layanan investasi M-Dinar mulai tanggal 15 Juli 2010 dengan batas pengembalian tanggal 15 Agustus 2010. Kuesioner yang kembali sebelum batas pengembalian sebanyak 135 kuesioner. Setelah dilakukan pemeriksaan data terdapat 11 kuesioner yang pengisiannya tidak lengkap sehingga dipergunakan sampel sebanyak 124 kuesioner. Sampai dengan batas pengembalian yang telah ditentukan pada tanggal 15 Agustus 2010 sampai hari selanjutnya tidak terdapat pengembalian kuesioner. Dari data distribusi kuesioner yang telah dilakukan maka yang layak menjadi data penelitian ini untuk diproses berjumlah 124 sehingga response ratenya 82,67\%.

\section{Evaluasi Measurement (Outer) Model}

Pengujian discriminant validity adalah bahwa indikator pada suatu konstruk akan mempunyai loading factor terbesar pada konstruk yang dibentuknya daripada loading factor dengan konstruk yang lain. Dari tabel 4.4 yang menguji outer model menunjukkan bahwa kontruk dari variabel dalam penelitian ini rata-rata di atas 
0,50. Hanya 3 kontruk yang nilainya di bawah 0,5, yaitu kontruk keempat dari variabel ekspektasi usaha yang sebesar 0,3256, kontruk keempat dari variabel pengaruh sosial yang sebesar 0,3109, dan konstruk dari variabel perilaku menggunakan M-Dinar yaitu sebesar 0,1936.

Konstruk dinyatakan reliabel jika memiliki nilai composite reliability di atas 0,70. Dari hasil output PLS di atas hampir semua konstruk memiliki nilai composite reliability di atas 0,70, hanya konstruk perilaku menggunakan M-Dinar yang nilainya di bawah 0,70 yaitu sebesar 0,59678. Jadi dapat disimpulkan bahwa hanya konstruk perilaku menggunakan M-Dinar yang tidak memiliki reliabilitas yang baik.

\section{Pengujian Model Struktural (Inner Model)}

Setelah model yang diestimasi memenuhi kriteria discriminant validity berikutnya dilakukan pengujian model struktural (inner model). Menilai inner model adalah melihat hubungan antara konstruk laten dengan melihat hasil estimasi koefisien parameter path dan tingkat signifikansinya (Ghozali Imam., 2008). Berikut adalah nilai $R$-square pada konstruk menunjukkan bahwa nilai $R$-square perilaku menggunakan M-Dinar (Use Behav) adalah sebesar 51,87\%. Hal tersebut berarti bahwa minat menggunakan (behavioral intention/Belnt) mampu menjelaskan perilaku menggunakan M-Dinar (Use Behav) dan kondisi yang memfasilitasi (FacCond) sebesar $51,87 \%$, sedangkan sisanya dijelaskan oleh variabel lain. Konstruk minat menggunakan (Belnt) dijelaskan oleh ekspektasi kinerja, ekspektasi usaha, persepsi kredibilitas dan pengaruh sosial sebesar 91,124\% dan sisanya dijelaskan oleh variabel lain.

\section{Pengujian Hipotesis}

Dasar yang digunakan dalam menguji hipotesis adalah nilai yang terdapat pada output result for inner weight berikut ini:

\section{Pengujian Hipotesis 1}

Dari tabel tersebut dapat dilihat terdapat hubungan yang positif (koefisien parameter 0,152) tetapi tidak signifikan antara ekspektasi kinerja dengan minat menggunakan M-Dinar karena memiliki nilai t statistik dibawah 1,96, yakni sebesar 1,4833. Dan umur, gender dan pengalaman tidak memoderasi hubungan antara ekspektasi kinerja dengan minat menggunakan M-Dinar.

\section{Pengujian Hipotesis 2}

Dari tabel tersebut dapat dilihat terdapat hubungan yang positif (koefisien parameter 0,056) tetapi tidak signifikan antara ekspektasi usaha dengan minat menggunakan M-Dinar karena memiliki nilai t statistik dibawah 1,96, yakni sebesar 0,6229. Dan umur, gender dan pengalaman tidak memoderasi hubungan antara ekspektasi kinerja dengan minat menggunakan M-Dinar.

\section{Pengujian Hipotesis 3}

Dari tabel tersebut dapat dilihat terdapat hubungan yang positif (koefisien parameter 0,055) tetapi tidak signifikan antara persepsi kredibilitas dengan minat menggunakan M-Dinar karena memiliki nilai t statistik dibawah 1,96, yakni sebesar 0,6618. Dan umur, gender dan pengalaman tidak memoderasi hubungan antara ekspektasi kinerja dengan minat menggunakan M-Dinar.

\section{Pengujian Hipotesis 4}

Dari tabel tersebut dapat dilihat terdapat hubungan yang positif (koefisien parameter 0,0346) dan signifikan antara pengaruh sosial dengan minat menggunakan M-Dinar karena memiliki nilai t statistik di 
atas 1,96, yakni sebesar 3,6053. Tetapi umur, gender dan pengalaman tidak memoderasi hubungan antara ekspektasi kinerja dengan minat menggunakan M-Dinar.

\section{Pengujian Hipotesis 5}

Dari tabel tersebut dapat dilihat terdapat hubungan yang positif (koefisien parameter 0,006) tetapi tidak signifikan antara kondisi yang memfasilitasi dengan perilaku menggunakan M-Dinar karena memiliki nilai $\mathrm{t}$ statistik dibawah 1,96, yakni sebesar 0,1897.

\section{Pengujian Hipotesis 6}

Dari tabel tersebut dapat dilihat terdapat hubungan yang positif (koefisien parameter 0,006) tetapi tidak signifikan antara kondisi yang memfasilitasi dengan perilaku menggunakan M-Dinar karena memiliki nilai $t$ statistik dibawah 1,96, yakni sebesar

\section{SIMPULAN}

Berdasarkan analisis dan pembahasan pada bagian sebelumnya, maka dapat ditarik kesimpulan sebagai berikut:

1. Ekspektasi kinerja, ekspektasi usaha serta persepsi kredibilitas tidak mempunyai pengaruh terhadap minat seseorang untuk menggunakan teknologi M-Dinar. Faktor kegunaan, kemudahan dan keamanan bukanlah merupakan faktor yang mempengaruhi minat seseorang untuk menggunakan teknologi M-Dinar. Begitu juga dengan umur, jenis kelamin serta pengalaman seseorang tidak mempunyai pengaruh terhadap minat seseorang untuk menggunakan teknologi M-Dinar

2. Pengaruh sosial, yaitu seorang yang mempunyai pengaruh besar atau sangat berarti bagi seseorang sangat mempunyai pengaruh terhadap minat seseorang untuk menggunakan teknologi M-Dinar. Seseorang mempunyai minat untuk menggunakan teknologi M-Dinar karena pengaruh dari lingkungan sosial tempat dia bekerja ataupun tinggal dan melaksanakan kegiatan bersosialisasi.

3. Kondisi yang memfasilitasi dan minat menggunakan teknologi M-Dinar tidak mempunyai pengaruh terhadap perilaku untuk menggunakan teknologi M-Dinar. Karena kondisi perusahaan yang tidak memberikan fasilitas kepada seseorang untuk menggunakan teknologi M-Dinar sangat berpengaruh sekali terhadap perilakunya untuk menggunakan teknologi M-Dinar, dan seseorang yang berminat belum tentu mau untuk menggunakan teknologi M-Dina dengan rutin.

\section{DAFTAR REFERENSI}

Amoroso, D.L. and Gardner, C. 2004. " Development of an Instrument to Measure the Acceptance of Internet Technology by Consumers." Proceedings of the Hawaii International Conference on System Sciences.

Bodnar George H dan William S. Hopwood. 2005. "Sistem Informasi Akuntansi". Buku Keenam. Edisi Indonesia.

[Terjemahan]. Jakarta: Penerbit Salemba Empat.

C. Kim, M. Mirusmonov, In Lee. 2010." An Empirical examination of factors influencing the intention to use mobile payment". Computers in Human Behavior 26 (2010) 310- 322 
Davis, F.D. 1989. "Perceived Usefulness, Perceived Ease of Use, and user acceptance of Information Technology." Management Information System Quarterly, Vol. 13, pp.319-340.

Dong-Hee Shin. 2009. "Towards an understanding of the consumer acceptance of mobile w wallet ". Computers in Human Behavior 25 1343-1354

Handayani. 2007. "Analisis Faktor-Faktor yang Mempengaruhi Minat Pemanfaatan Sistem Informasi dan Penggunaan Sistem Informasi." Kumpulan Materi Simposium Nasional Akuntansi X. Makasar, 26 - 28 Juli 2007.

Hermawan, Arief. 2006. " Pengembangan Model Penerimaan Penggunaan Internet Mahasiswa Program Studi Manajemen Informatika D III Universitas Teknologi Yogyakarta." http://smkn3-kuningan.net/seminar uny/20_Arief\%20Hermawan.pdf. Diakses 10 Januari 2010.

Jogiyanto. 2007. "Sistem Informasi Keperilakuan". Yogyakarta. Penerbit: Andi.

P. G. Schierz, O. Schilke, B.W. Wirtz. 2009. „Understanding consumer acceptance of mobile payment services: An empirical analysis „. Electronic Commerce Research and Application XXX (2009) XXX-XXX

S. Al Awadhi, A. Morris. 2008. "The Use of the UTAUT Model in the Adoption of E- $\quad$ government Services in Kuwait". Proceedings of the $41^{\text {st }}$ Hawaii International Conference on System Sciences.

T. Zhou,Y. Lu, B. Wang. 2010., Integrating TTF and UTAUT to explain mobile banking user adoption ". Computers in Human Behavior xxx (2010) $x x x-x x x$

T. Zhou. 2008. "Towards Exploring Mobile User Acceptance Based on UTAUT and Contextual Offering". International Symposium on Electronic Commerce and Security.

Thompson, Ronald L., Higgins, Christoper A, dan Howell, Jane M. 2000. " Personal Computing: Toward a Conceptual Model Utilization". MIS Quarterly. March 1991. pp. 125-143.

Venkatesh, V., and Davis, F.D., 2000. "A Theoritical Extension of the Technology Acceptance Model: Four Longitudinal Field Studies." Management Science. Vol.46. No.2. Februari. pp.186-204.

Venkatesh, V., and Moris, M.G., 2002. “Why Don't Men Ever Stop to Ask for Directions? Gender, Social Influence and Their Role in Technology Acceptance and Usage Behavior." MIS Quarterly. Vol.24. No.1. March.pp 115139.

Venkatesh, V., Moris, M.G., Davis, G.B., and Davis F.D., 2003. “User Acceptance of Information Technology: Toward a Unified View". MIS Querterly. Vol.27. No.3. September. pp.425-475.

Wang, Y,. Y. Wang, H. Lin, dan T. Tang. 2003. „Determinants of User Acceptance of Internet Banking: an Empirical Study“. International Journal of Service Industry Management. 14(5). pp. 501-519

Y. A. Au, R. J. Kauffman. 2008. "The economics of mobile payment: Understanding $\quad s t$ a k e h o I d e r issues for an emerging financial technology Application". Electronic Commerce Research $a n d$ Application 7 (2008) 141-164 
Lampiran

Tabel 1

Hasil PLS Algorithm

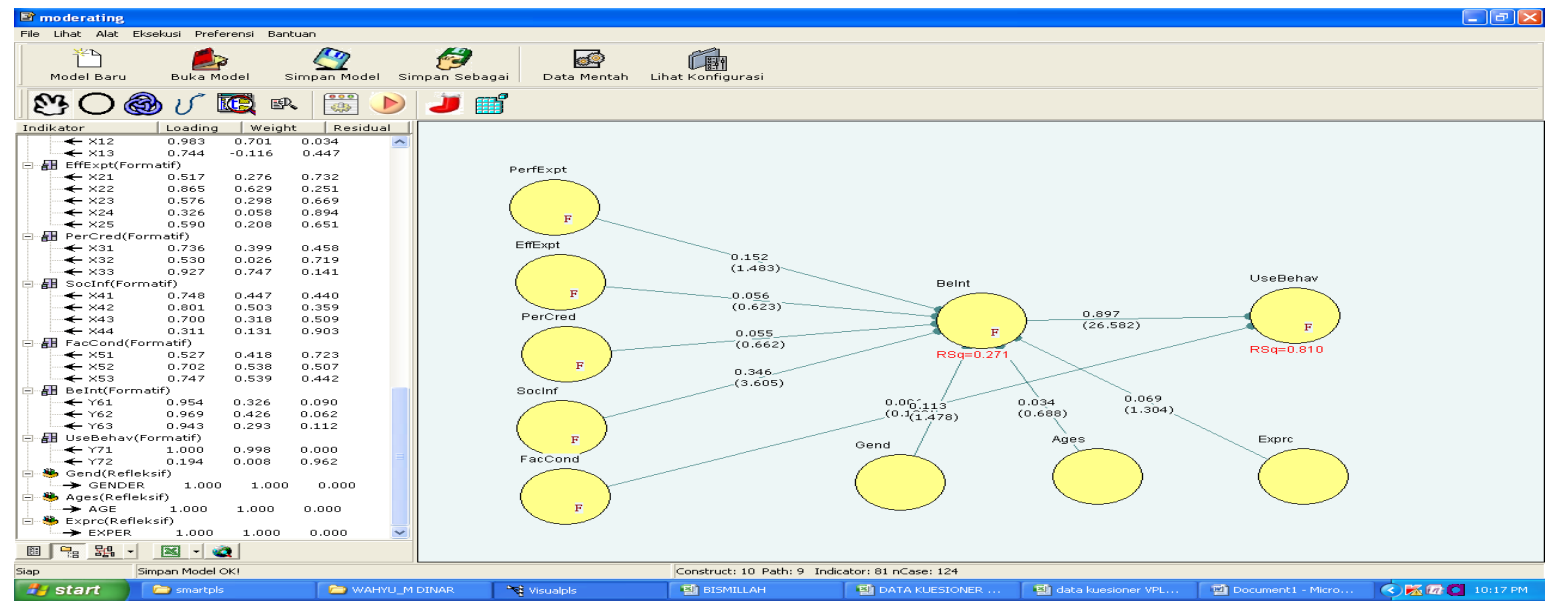

Tabel 2

Result for inner weight

Entire

Mean of

Sample

Subsamples

Standard Error

T Statistics

Estimate

$\begin{array}{lllll}\text { PerfExpt -> BeInt } & 0.152 & 0.1626 & 0.1025 & 1.4833 \\ \text { Gend -> BeInt } & 0.113 & 0.1258 & 0.0764 & 1.4781 \\ \text { Ages -> BeInt } & 0.034 & 0.0767 & 0.0494 & 0.6881 \\ \text { Exprc -> BeInt } & 0.069 & 0.0759 & 0.0529 & 1.3036\end{array}$

Gambar 1. Theory of Reasoned Action (TRA)

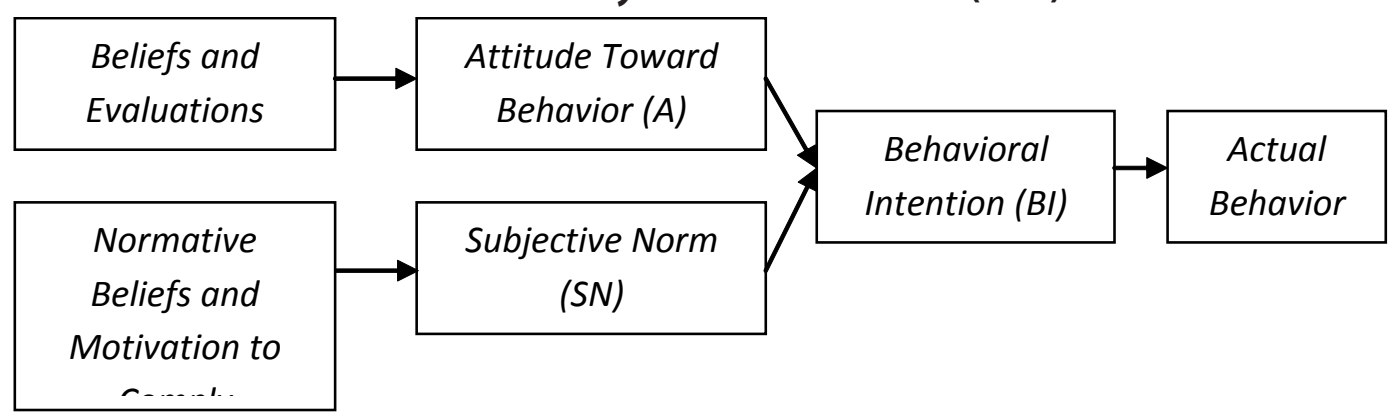

(Sumber : Ajzen dan Fishbein, 1975 yang dikutip oleh Davis et. al 1989) 
Gambar 2. Theory of Planned Behavior (TPB)

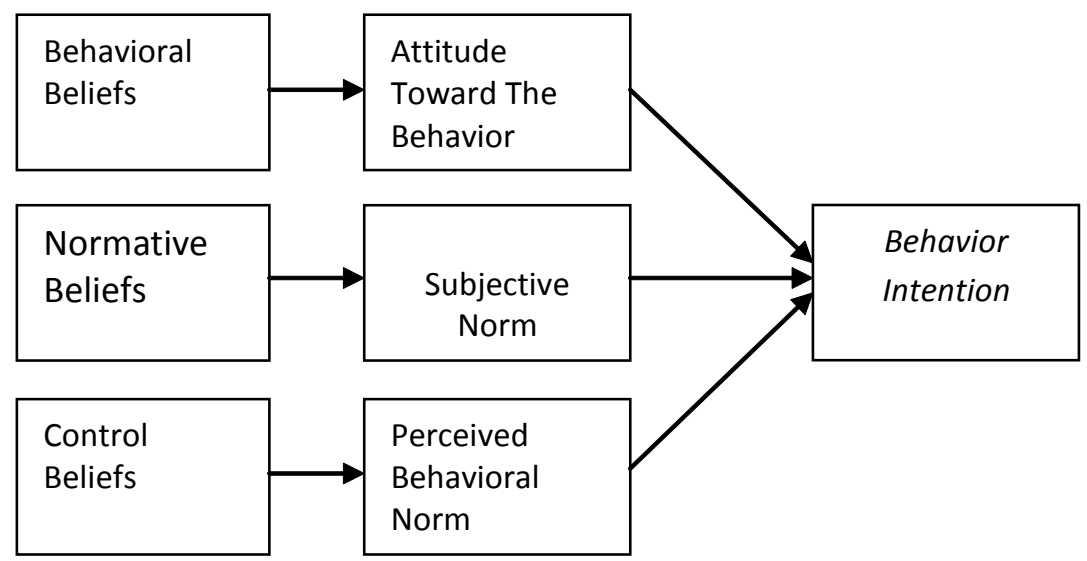

(Sumber: Ajzen dan Fishbein, 1988)

Gambar 3. Kerangka Penelitian

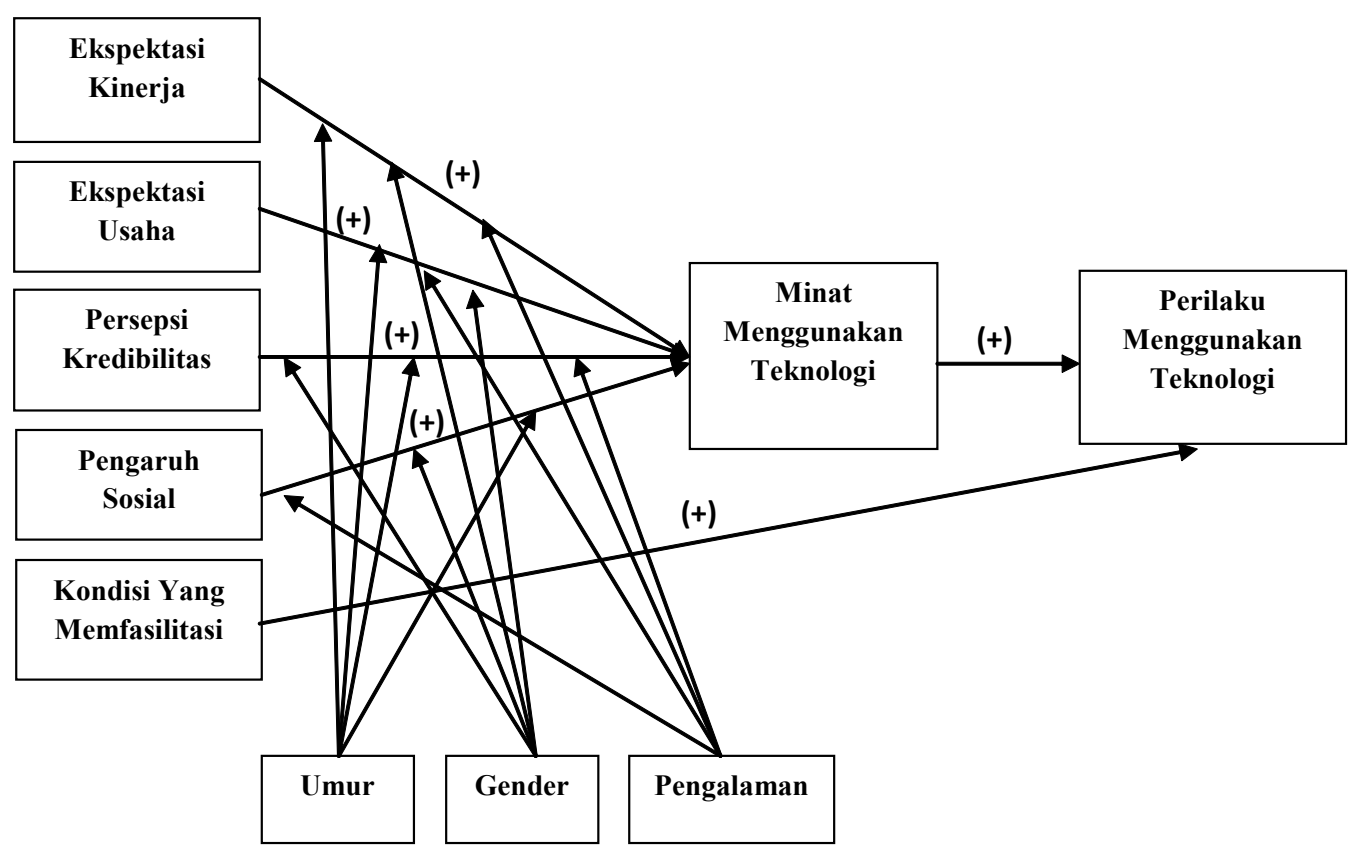

